\title{
The health insurance market: lessons on the conflict between equivalence and solidarity
}

\author{
Andras Uthoff, José Miguel Sánchez and Rolando Campusano
}

ABSTRACT

Health-care systems are highly diverse, sometimes even sharing few basic aspects of design. In developing countries, demographic profiles, poverty, the labour market and public finances are such that a comprehensive approach to solidarity _combining contributory and non-contributory mechanisms - is essential. In 1981, Chile redesigned the contributory component of its system by means of private health-insurance companies. The rationale of private, individual insurance runs counter to the ethical imperatives of contracts based on social rights. In Europe, this dilemma has been tackled using risk-levelling mechanisms that resolve the conflict between accessibility, efficiency and selection. In Chile, competitive health insurance companies (Isapres) coexist with a solidarity-based State alternative, the National Health Fund (FONASA). The Isapres engage in aggressive risk selection. The challenge for health policy is to integrate the two systems to balance the principles of equivalence and solidarity.

KEYWORDS

JEL CLASSIFICATION

AUTHORS
Health, health insurance, health services, financing, solidarity, risk, right to health, public sector, private sector, case studies, Chile

$\mathrm{I} 11, \mathrm{I} 13, \mathrm{I} 14$

Andras Uthoff is a Professor at the Faculty of Economy and Business of the Universidad de Chile and a member of the Previsional Consultory Board. andrasut@gmail.com

José Miguel Sánchez is an Advisor to the Health Management Institute of the Universidad de Chile. sanchezb.josemiguel@gmail.com

Rolando Campusano is an Economic Analyst at the Central Bank of Chile. rcampusano@bcentral.cl 


\section{I}

\section{Introduction}

A large body of literature exists analysing the conditions under which individual insurance schemes are useful for financing public health systems. The research explores why health insurance markets - in which subscribers are free to choose between insurance companies- generate heavy incentives not only for efficiency, but also for risk classification, segmentation and selection, which runs counter to the normative framework of social protection as it refers to health. Given that universal access is one of the main objectives of social insurance schemes, whereas markets for individual insurance impose a variety of selection processes, the basic question arises: Can high-risk individuals be assured of accessible coverage in an individual health insurance market?

The problem is that competitive markets tend to seek "equivalence" between the premium and the costs each contract is expected to generate. They are, therefore, poorly placed to provide "solidarity" by offsetting the probable losses arising from contracts with high-risk individuals with the profits presumed to flow from contracts with low-risk individuals, precisely because competition minimizes foreseeable profits.

Insurance companies make use of a variety of selection mechanisms:

- Risk classification: adjusting the insurance premium for each plan to individual risk.

- Risk segmentation: adjusting the insurance plan (i.e. benefit coverage and design) to attract different risk groups to each plan and charge a premium accordingly.

- Risk selection: adjusting subscribers' risk to the premium set for a given health plan.

Steps were taken in the third generation of reforms to Latin America's health systems to combat these effects, including explicit guarantees in Chile, the model of the Single Health System (sus) in Brazil, the creation of the National Integrated Health System in Uruguay, and regulated competition in Colombia. These were all efforts to work towards universal access through a mix

Paper presented by the authors at the Conference on Health and Socio-Economic Development in Latin America, organized by the Faculty of Economy and Business of the Universidad de Chile and RAND Corporation on 14-15 November 2011. of contributory and non-contributory funding, aiming to extend health services to the entire population through solidarity from rich to poor, from young to elderly, from the healthy to the sick.

In its publication Shaping the Future of Social Protection: Access, Financing and Solidarity, the Economic Commission for Latin America and the Caribbean (ECLAC, 2006) identifies three types of interaction between public financing and social security contributions (see table 1):

Type 1: integrated system based on non-contributory financing.

Type 2A: integrated system which retains contributory financing and a single level of coverage delivered via social security.

Type 2B: integrated system with coverage differentiated between contributory and non-contributory financing. Type 3: systems with little or no integration.

Chile uses a modality of articulation between the public and social-security systems, which may be construed as dual and partial. Its key feature is segmentation, inasmuch as mandatory health contributions can be paid to either of two health insurance systems that operate in parallel but have very different rationales. Contributors must choose between the National Health Fund (FONASA), a public health insurance scheme, and private health-insurance policies offered by companies called Isapres, which operate within the social security domain.

The funding of the public system and social security are articulated in the framework of FONASA, which is financed from the contributions paid by affiliates, supplemented from general tax revenues (in the case of individuals who are unable to contribute). Insofar as the system is financed in this combined manner and individuals may access benefits independently of their contributions, FONASA provides risk and income solidarity. However, the duality of the system and the individual nature of insurance in Isapres create obstacles to full integration of financing and to greater equity. Higher-income individuals tend to enrol in the Isapre system, especially at the stage of the life in which health 
Latin America and the Caribbean: combinations of public funding and social security contributions in the health sector

\begin{tabular}{|c|c|c|}
\hline Type 1 & Type 2 & Type 3 \\
\hline $\begin{array}{l}\text { Financing: general revenues, integrated } \\
\text { systems based on non-contributory financing }\end{array}$ & $\begin{array}{l}\text { Financing: integration of general revenues and } \\
\text { social security contributions }\end{array}$ & $\begin{array}{l}\text { Financing: little or no integration of general } \\
\text { revenues and social security contributions }\end{array}$ \\
\hline $\begin{array}{l}\text { Services are structurally varied between } \\
\text { public and private providers }\end{array}$ & $\begin{array}{l}\text { In all cases there is some degree of explicit } \\
\text { separation between financing and service } \\
\text { delivery functions. The level of integration of } \\
\text { financing also varies }\end{array}$ & $\begin{array}{l}\text { The structure of public services is } \\
\text { heterogeneous, and different types of } \\
\text { relationship exist between the public and } \\
\text { private sectors }\end{array}$ \\
\hline $\begin{array}{l}\text { Public and private service provision: } \\
\text { Bahamas, Barbados, Belize, Brazil, } \\
\text { Dominica, Grenada, Guyana, Haiti, Jamaica, } \\
\text { Saint Kitts and Nevis, Saint Vincent and the } \\
\text { Grenadines, Suriname, Trinidad and Tobago, } \\
\text { Venezuela (Bolivarian Republic of) b } \\
\text { Service provision through the public system } \\
\text { only: Cuba }\end{array}$ & $\begin{array}{l}\text { Type 2A: Integrated, maintaining contributory } \\
\text { financing and uniform set of services delivered } \\
\text { via social security: Costa Rica } \\
\text { Type 2B: Integrated with coverage } \\
\text { differentiated by contributory status: Antigua } \\
\text { and Barbuda, Colombia, Dominican Republicc } \\
\text { Type 2C: Dual model with partial integration: } \\
\text { Chile }\end{array}$ & $\begin{array}{l}\text { Argentina, Bolivia, Ecuador, El Salvador, } \\
\text { Guatemala, Honduras, Mexico, Nicaragua, } \\
\text { Panama, Paraguay, Peru, Uruguay }\end{array}$ \\
\hline
\end{tabular}

Source: Economic Commission for Latin America and the Caribbean (ECLAC).

Note: In all countries, except Cuba, there is also a private subsector that provides health services.

a In Haiti there is practically no social security, and the provision and financing of health services are undertaken basically by the public sector and non-governmental organizations (NGOs).

b The reforms of the last few years have elicited greater participation and coverage in the public system.

c Both Antigua and Barbuda and the Dominican Republic are in a transition period, implementing health reforms aimed at greater integration of financing.

risks are relatively low; accordingly, they pay high contributions and carry low risk, but do not participate in contributory solidarity.

This paper examines this dilemma with reference to Chile, as a case of individual insurance schemes in the context of Latin America. The work is organized as follows: Section II discusses the implications of risk selection for well-being, section III draws lessons from the European experience and section IV looks at the implications for Chile. Section V concludes.

\section{II}

\section{Conceptual considerations on health-care equity}

\section{Equity-driven interventions in the health-care market ${ }^{1}$}

Equity in health-care provision has to do with notions of social justice. As applied to health, economic theory distinguishes two forms of equity: horizontal and vertical. Horizontal equity as it refers to health is equal treatment for people with equal needs. ${ }^{2}$ The idea

\footnotetext{
1 Adapted from Barr (2003).
}

2 This means that people with the same clinical needs should receive the same clinical treatment; equal access for equal needs; equal resources used for equal expected health outcomes; equal funds per capita for equal needs. of vertical equity is that individuals of different types should be treated differently. ${ }^{3}$

Looked at in this manner, there are three arguments for intervening in the health-care market. First, to distribute information and power and ensure horizontal equity, thereby endowing affiliates in the system with perfect information and equal power to take decisions and access the various health plans the system has to offer. But access to information is costly and the ability

3 In taxation terms, this means that individuals with greater resources should pay more tax (or larger contributions to the health system) than the poor, thereby generating solidary redistribution from rich to poor. 
to understand rights is unequal: this systematically disadvantages poorer socioeconomic groups and ultimately restricts their options. The solutions include regulation to ensure minimum standards, ${ }^{4}$ price subsidies (for prescriptions, for example), income subsidies (monetary transfers) and, in extreme cases, State assignation or production, or both.

Second, to include consumption externalities, to make the rich pay higher premiums than the poor to consume the same quantity (or plan). ${ }^{5}$ This may be rationalized in terms of concern for the needs of others, whether for reasons of national efficiency ${ }^{6}$ or altruism. ${ }^{7}$

The third argument is that health care is a public good and as such should be exempted from economic calculations and provided outside the market. There are ethical and philosophical reasons that justify a morally superior method of distribution. But health care is also an economic good, which includes rivalries (the time a doctor devotes to one patient is time denied to another) and exclusivity (health care competes for resources with other possible allocations), which makes it a private good. So, although health care is a morally superior good, serious allocation problems arise if it is left to a market of pure competition governed by the forces of supply and demand with no intervention by some kind of authority. In this case, intervention is necessary to ensure the good's provision.

These notions give rise to several roles for the State. The first is that health care should be treated as a merit good to be distributed among the population in accordance with certain equity criteria and access should depend on need. Hence the importance that resources should be distributed by the State (either by setting down minimum health-care standards for the most vulnerable, or by limiting the current inequities in access to health care).

The second role for the State is to close information gaps with regulatory policies to shed light on complex biological processes, accredit professionals and services,

\footnotetext{
4 Of the professional qualifications of nurses and doctors, and of medicines, treatments and medical facilities, in both public and private sectors, in order to ensure that horizontal equity is satisfied.

5 Or to ensure that if the rich consume twice as much as the poor, they also pay twice as high a contribution.

6 Given that access to health services improves the quality of the workforce, labour productivity and economic growth, and that meeting the health-care needs of the most vulnerable averts social discontent.

7 That is, the distribution of health care per se, in which health care is transferred to the poor in kind. Thus they are acknowledged as rights-bearing citizens, whereas targeted monetary transfers are perceived in terms of welfarism and poverty stigmatization.
}

make health insurance plans transparent and avoid adverse selection.

A third role for the State is to invest directly or indirectly in health and health-care infrastructure (public drainage, hospitals and health posts, etc.) and in training health professionals. The complexity of these investments and the advanced knowledge and technology they require make them public goods which should be provided or subsidized by the State.

Lastly, a fourth role is lies in the regulation and tax treatment of goods generated by health status externalities, whether positive (physical activity, clean environment, and so forth) or negative (tobacco addiction, sedentary lifestyle, obesity, among others).

\section{The scheme of health-care financing is not equity-neutral}

The way the financing structure of the health-care system is designed imposes major limitations on social justice. Financing structure is usually designed around three alternatives: (i) production and allocation by the market (with or without insurance); (ii) intermediate strategies, and (iii) production and allocation by the State.

\section{(a) Provision by the market only, without insurance}

If health-care provision is treated as an economic good and delivered in market of pure competition, without insurance, then consumption will be limited by price. The equilibrium quantity may exceed (uncompetitive supply-side behaviour) or undershoot the optimum level (unincorporated externalities, uncompetitive supply-side behaviour, or both). The outcome will be inefficient allocation of total resources (macro-inefficiency) and of the volume and placement of benefits among the alternatives (micro-inefficiency). As well as inefficient, the system will be unequal, since health care will be determined by income distribution, and these inequalities will be greater where knowledge and power are correlated with income (the poor are the most disadvantaged), and in the presence of a perfect capital market and the absence of insurance. The end result will be underconsumption of the health-care "good", especially by the poorest and most at-risk.

\section{(b) Provision by the market only, with insurance}

Those on the demand side of the health-care equation face uncertainty, because as patients they do not know how much health care they will need or when they will need it. Neither do they know the outcome probabilities for different treatments or the relative efficiency of the 
various health-care providers. One solution is to enter the health-insurance market. Where insurance pays all medical bills, consumption is not limited by price and is determined by the supplier. The uncertainty of the patient demand curve thus becomes less important.

But insurance markets can have a perverse impact on health-care market outcomes: ${ }^{8}$ moral hazard exists wherever the doctor has no supply-side incentives to ration demand. There will be a tendency towards overconsumption of benefits, because payment by a third party (the insurer) generates incentives towards waste and overuse. "Social inequity" exists with insurance, too, because some individuals are unable to buy an insurance scheme: the poor, the elderly and the chronically ill and others who, without being any of these things, simply cannot afford premiums driven up to inaccessible levels by overconsumption in the insurance market. This problem is exacerbated by insurance companies' use of selection mechanisms: be it by classifying risk by adjusting the premium for each plan to individual risk; segmenting risk by adjusting the plan (i.e. benefit coverage and design) to attract different risk groups to each plan and charge a premium accordingly; or selecting risk by adjusting affiliates' risk to the premium set in the plan. ${ }^{9}$

\section{Intermediate strategies: the public-private mix}

One solution to these dilemmas is a health system somewhere between public and private model. The design of such a system must be: (i) more efficient and equitable than the other solutions, and (ii) more acceptable, politically speaking, than other arrangements.

There are two coherent types of mixed strategies. One, where health care is delivered by some kind of health maintenance organization (HMO), ${ }^{10}$ affiliation is mandatory and insurance premiums are paid by the individual (or by income transfers for the poor). The

\footnotetext{
8 This can occur is five conditions are met: (i) the probability of needing treatment must be independent from one individual to another; (ii) it must be less than 1; (iii) it must be known or estimable; (iv) it must not be able to be hidden (adverse selection), and (v) it cannot be manipulated (moral hazard).

9 This does not imply that competitive private markets cannot exist for health-care inputs (meals, beds, medicines, towels, X-ray machines, and so forth). What is more, private input suppliers probably make that market become more efficient and preferable.

10 An HMO is a private corporation holding contracts with doctors, hospitals and employers, which provides individual health insurance in exchange for a fixed cost or premium. Individuals must choose a primary care physician within the HMO network, through whom all health-care decisions will be channelled (medication, hospitalization, tests and referrals).
}

other, when health care is delivered privately (not via an HMO), paid by the State (directly, through social security, or through a regulated medical insurance) and the total product or expenditure is controlled by the State, either directly or through a general budget cap.

\section{(a) Health-care production}

In a mixed (public-private) system, the idea is to prevent out-of-pocket payments or third-party contributions from creating efficiency disparities or impeding the incorporation of externalities. Moral hazard must also be avoided by monitoring physicians' decisions, either by administrative measures or by budget constraints. Externalities are internalized by aligning the activities of the physician with those of the insurance company, forcing doctors to assume the marginal social costs of treatment prescribed. In HMOs the doctors themselves are the insurance providers, which internalizes the externalities and eliminates the incentive to overprescribe. In other cases, a limited network of doctors or a preferred provider organization (PPO) delivers administered health-insurance plans. In this case, an insured person receiving treatment from a preferred provider need pay only the pre-established copayments. This sort of plan enables affiliates to predict out-of-pocket expenditures. The insurance company then pays the rest of the cost of treatment to the provider without involving the insured party.

A PPO differs from an HMO in that the insured party is freer to seek treatment outside the network of physicians and hospitals, and is not limited to the insurer's own resources. Different tools are used to protect the quality and cost of care, including oversight of the programmes administered, changes in the way physicians are paid, education programmes and restrictions on provider networks.

\section{(b) Financing health care}

There are two types of intermediate organizations:

\section{- Private financing, complemented by the State:}

Three groups may be identified in this system: (i) the non-poor, (ii) the uninsurable (elderly, children and expectant mothers, poor and non-poor with congenital and/or chronic illnesses), and (iii) the poor.

For the non-poor, the system operates through private insurance, subject to two types of regulation: threshold standards of coverage and the obligation to ensure that no externalities are associated with noninsurance (adverse selection). 
For the other two groups, the solution falls to the State, which subsidizes private insurance premiums fully, partially or both, as the case may be. Here, three problems arise: (i) a targeting problem related to the definition of health-care problems to be included, what guarantees of assistance the State will offer and what income level will trigger subsidization; (ii) developing the institutions to monitor and avoid oversupply, and (iii) the moral hazard that arises in this sort of scheme when rich individuals try to qualify as poor in order to secure State assistance.

\section{- Social security:}

The State pays medical bills through social security or general taxes. These are multi-payer systems in which health care is delivered indirectly. The best known system of this type is Germany's. Usually, the system is funded principally from payroll taxes. An analytically equivalent arrangement is obligatory affiliation to private, regulated and non-profit insurance institutions which act as agents of the State. This arrangement has two advantages: (i) since the scheme is obligatory, it encourages premium-setting by payment capacity, rather than by risk, with no loss of efficiency, and (ii) its universal coverage (of individuals and risks) sidesteps the difficulties of setting limits. Such social security institutions, because they are not strictly actuarial (for example, in not adjusting premiums to individual risk levels) can avoid the weaknesses of individual private insurance schemes.

\section{Production, allocation and financing by the State}

With State financing, the production of health care, quality control and the role of the insurance companies therein is assumed to be justified by imperfect consumer information. These two forms of oversight could be more effective if health care was produced by the State. It is also assumed that State production solves the problems of imperfect information of private insurance companies (the problems of the third-party payer), and makes all medical conditions insurable. It is also said to avoid large and inefficient increases in the production of health care.

This option is debatable inasmuch as it requires two conditions to be fulfilled: that the conditions for market efficiency fail (information problems), and that public production and allocation are less efficient than any other alternative (which is harder to establish).

This would mean proving that: (i) the treatment physicians decide upon largely resolves the difficulties arising from consumer ignorance; (ii) if it is financed (almost entirely) from general taxes, health care is largely free and excludes no one; (iii) if doctors receive little or no payment for their services, the incentives for oversupply by a third payer are reduced, and (iv) health care is rationed explicitly, partly by administrative measures, partly by the existence of budgetary limits. The idea is to limit the overconsumption generated by moral hazard.

\section{III}

\section{The international experience with private health insurance markets ${ }^{11}$}

\begin{abstract}
At the international level, it is worrisome that in health insurance markets, in which subscribers are free to choose between insurers, strong incentives arise for insurance companies not only to seek efficiency, but also to classify, segment and select risk. ${ }^{12}$ This runs

\footnotetext{
11 On the basis of Van de Ven and Schut (2011).

12 In this regard, it will be recalled that: (i) classifying risk is adjusting the insurance premium for each product according to individual risk; (ii) segmenting risk is adjusting the product (i.e. benefit coverage and design) the attract certain groups for each product and charge them premiums accordingly, and (iii) selecting risk is adjusting accepted risk to the premium set for a given product.
}

counter to the principle of universal access, one of the main objectives of social security schemes. The question then arises:

\section{How can high-risk individuals be assured of accessible coverage in an individual health insurance market?}

Within the intermediate solutions discussed in the previous section, a number of countries have developed formulas for guaranteeing accessible coverage for high-risk groups in individual health insurance 
markets. A system of "risk-adjusted subsidies" is the preferred form of subsidy for making individual health insurance accessible in a competitive insurance market in which the consumer is free to choose an insurance company. In this approach, insurers are free to charge risk-adjusted premiums.

A comparison of five countries with insurance including obligatory health plans (see table 2), shows that in all cases consumers have a period to choose between insurers (health plans), which are responsible for buying them or providing them with the care they need. In all cases there are strict regulations on the premium paid directly by the consumer; however, all have imperfect risk-adjustment formulas. For that reason, insurers (health plans) have strong financial incentives for risk selection, which undermines solidarity, efficiency and care quality. Unless improvements are made to risk-adjustment formulas, risk selection is only likely to increase. This has become particularly serious in Germany and Switzerland. The analysis of the five cases concluded that public policy would be well advised to afford a high priority to improving risk-adjustment formulas. This can be achieved more readily by incorporating factors to adjust for morbidity. This same conclusion was found to be valid for other countries with competitive health insurance markets or insurance schemes like those in Argentina, Australia, Chile, Colombia, the Czech Republic, Ireland, the Russian Federation, Slovenia, Poland and the United States. Arriving at good adjustments for morbidity risk is the only effective strategy ${ }^{13}$ for avoiding risk selection without loss of solidarity and without distorting competition between health risk plans.

Political, economic and pragmatic considerations come into determining how payment of risk-adjusted subsidies is organized. In practice, all the counties which use risk-adjusted subsidies stipulate the subsidy to the insurer, which reduces the consumer's premium by the per capita subsidy allowed by the adjustment mechanism to insure that consumer. This approach to organizing subsidies is termed "risk equalization". It uses age and sex as risk adjusters, often alongside indicators of disability and institutional status and well-being. Thus far, only the Netherlands and the United States (Medicare ${ }^{14}$ ) have used morbidity-adjustment factors.

Risk-adjusted subsidies or "risk equalization" can be complemented with three mechanisms: (i) premiumbased subsidies; (ii) offsets for excessive losses, or (iii) implicit cross-subsidies through restrictions on premiums for certain types of coverage. The better the premium subsidy is adjusted for relevant risk factors, the less necessary these three strategies and the less conflict there will be.

In practice, the most popular complementary strategy is community rating, which consists of obliging insurers to charge every affiliate the same premium for the same product, regardless of individual risk. This practice has short-term advantages, such as greater equity and service access. In the long term, it can make the system insolvent, mainly owing to the disincentives to provide good care to the chronically ill or, even if those incentives are well structured, can make the system unsustainable over time.

At least half the countries of the Organisation for Economic Cooperation and Development (OECD) have opted to provide tax subsidies to promote the purchase of private health insurance (deductions from taxable income). Some of these subsidies are quite considerable, such as in the case of Australia, with a $30 \%$ premium tax rebate and in the United States, with a $35 \%$ tax subsidy on health insurance. The analysis concludes that great strides could be made in terms of efficiency if premium subsidies were replaced by risk-adjusted subsidies.

The analysis of those five cases concludes that although a good risk equalization strategy helps to resolve the conflict between accessibility, efficiency and selection in a competitive individual insurance market, these strategies are still imperfect and need more investment in improving risk equalizing mechanisms. Such investment should include better databases and research and development of better risk adjusters.

\footnotetext{
13 Strictly speaking, the affirmation of "only strategy" is valid only taking into account the specific weight of pure goods, such as preventive aspects, the lifestyles promoted and, therefore, the role that national health systems should place in preventive care and promoting health (Wilkinson, 2006).
}

14 Social security programme administered by the Government of the United States, which provides medical care for persons over age 65 and operates as a form of personal insurance. 
International experience with risk adjustment and distribution

\begin{tabular}{|c|c|c|c|c|c|}
\hline & Belgium & Germany & Israel & Netherlands & Switzerland \\
\hline \multicolumn{6}{|c|}{ Situation pre-reform (1980s) } \\
\hline $\begin{array}{l}\text { Financial } \\
\text { responsibility }\end{array}$ & Zero & $\begin{array}{l}\text { High (but none for } \\
\text { pensioners) }\end{array}$ & High & Zero & High \\
\hline $\begin{array}{l}\text { Free choice of } \\
\text { programme }\end{array}$ & Yes & $\begin{array}{l}\text { Limited for } 60 \% \text { of } \\
\text { affiliates }\end{array}$ & Yes & No & $\begin{array}{l}\text { Yes, but insurers } \\
\text { allowed to charge the } \\
\text { elderly more }\end{array}$ \\
\hline Coverage restrictions & $\begin{array}{l}\text { Solidarity } \\
\text { contribution to } \\
\text { the health system, } \\
\text { which distributed it } \\
\text { equitably to insurers }\end{array}$ & $\begin{array}{l}\text { Fixed percentage } \\
\text { of contribution for } \\
\text { pensioners, but } \\
\text { variable for those } \\
\text { paying into the system }\end{array}$ & $\begin{array}{l}\text { Solidarity contribution } \\
\text { as fixed percentage of } \\
\text { income per contributor }\end{array}$ & $\begin{array}{l}\text { Solidarity } \\
\text { contribution to } \\
\text { the health system, } \\
\text { which distributed it } \\
\text { equitably to insurers }\end{array}$ & $\begin{array}{l}\text { Contribution } \\
\text { regardless of risk and } \\
\text { income }\end{array}$ \\
\hline Problems of selection & No & Yes & Yes & Yes & No \\
\hline \multicolumn{6}{|c|}{ Situation post-reform (year 2000) } \\
\hline $\begin{array}{l}\text { Adjustment } \\
\text { variables and use of } \\
\text { information }\end{array}$ & $\begin{array}{l}7 \text { variables using } \\
\text { retrospective } \\
\text { information }\end{array}$ & $\begin{array}{l}5 \text { variables using } \\
\text { retrospective } \\
\text { information }\end{array}$ & $\begin{array}{l}\text { One variable using } \\
\text { prospective information }\end{array}$ & $\begin{array}{l}5 \text { variables using } \\
\text { prospective } \\
\text { information }\end{array}$ & $\begin{array}{l}3 \text { variables using } \\
\text { prospective } \\
\text { information }\end{array}$ \\
\hline $\begin{array}{l}\text { Premium system and } \\
\text { solidarity fund }\end{array}$ & $\begin{array}{l}\text { One community } \\
\text { rating per insurer; } \\
\text { a percentage of } \\
\text { this premium } \\
\text { goes directly to a } \\
\text { solidarity fund }\end{array}$ & $\begin{array}{l}\text { Fixed percentage } \\
\text { of income for each } \\
\text { insurer. Then insurer } \\
\text { transfers a portion to } \\
\text { a solidarity fund }\end{array}$ & $\begin{array}{l}\text { No direct contribution } \\
\text { to insurer, but direct } \\
\text { contribution to a } \\
\text { solidarity fund }\end{array}$ & $\begin{array}{l}\text { One community } \\
\text { rating per insurer; } \\
\text { a percentage of } \\
\text { this premium } \\
\text { goes directly to a } \\
\text { solidarity fund }\end{array}$ & $\begin{array}{l}\text { One community rating } \\
\text { per insurer and region, } \\
\text { a percentage of this } \\
\text { premium goes directly } \\
\text { to a solidarity fund }\end{array}$ \\
\hline $\begin{array}{l}\text { Insurers' financial } \\
\text { responsibility }\end{array}$ & $\begin{array}{l}\text { No financial } \\
\text { responsibility for } \\
\text { capital costs of } \\
\text { hospitals }\end{array}$ & $\begin{array}{l}\text { No financial } \\
\text { responsibility for } \\
\text { capital costs of } \\
\text { hospitals }\end{array}$ & $\begin{array}{l}\text { Financial responsibility } \\
\text { for capital costs of } \\
\text { hospitals through a } \\
\text { payment included in } \\
\text { per diem premiums. }\end{array}$ & $\begin{array}{l}\text { Financial } \\
\text { responsibility for up } \\
\text { to } 5 \% \text { of the capital } \\
\text { costs of hospitals }\end{array}$ & $\begin{array}{l}\text { No financial } \\
\text { responsibility for } \\
\text { capital costs of } \\
\text { hospitals }\end{array}$ \\
\hline Risk sharing & $\begin{array}{l}\text { Proportional, all } \\
\text { eventualities }\end{array}$ & $\begin{array}{l}\text { No obligation to } \\
\text { share risk }\end{array}$ & $\begin{array}{l}\text { Conditioned by } \\
\text { payment of expenses } \\
\text { (ceiling } 6 \% \text { ) of } 5 \\
\text { serious illnesses. There } \\
\text { is also a safety net to } \\
\text { finance the deficit. }\end{array}$ & $\begin{array}{l}\text { Distribution of } \\
\text { outstanding risks, } \\
\text { proportional }\end{array}$ & $\begin{array}{l}\text { No obligation to } \\
\text { share risk }\end{array}$ \\
\hline
\end{tabular}

Source: W.P.M.M. Van de Ven and others, "Risk adjustment and risk selection on the sickness fund insurance market in five European countries", Health Policy, vol. 65, No. 1, Amsterdam, Elsevier, 2003.

\section{IV}

\section{The Chilean experience with individual health insurance}

The structure of Chile's health system was reformed by decree-law (No.3) in 1981. An individual health insurance system was created whereby, to avoid adverse selection, workers must pay in $7 \%$ of monthly income. Workers choose to pay their $7 \%$ into the public health fund (FONASA) or into the private system (Isapres). In the absence of regulation, this modality — which essentially has the merit of forcing higher earners to pay more- does not guarantee access to a health system in which risks are shared and solidarity assured. ${ }^{15}$

\footnotetext{
15 In fact, changes have been made almost continually to the Chilean health system and have been much more extensive than the creation of private insurance and the transformation of the Employees' National Medical Service (SERMENA) into FONASA, but a full account is beyond the scope of this work.
} 
The private market has offered insurance that is fair, in actuarial terms, at the level of each individual contract, but which encourages risk selection by the Isapres and impedes the solidarity necessary for a social covenant on health. Solidarity operates only when subscribers migrate to FONASA. In effect, the health system segmented subscriber contributions to reflect the inequalities ingrained in Chilean society, making the reform regressive in terms of the contributory health system. In 2010, payments of mandatory premiums amounted to 2.2 billion Chilean pesos (Ch\$) - equivalent to $2.1 \%$ of gross domestic product (GDP) ${ }^{16}$ _ of which $45.2 \%$ (Ch\$ 974 million) was collected by the Isapres, which cover only $16.5 \%$ of the population. The average obligatory monthly premium, which would have been $\mathrm{Ch} \$ 16,040$ pesos had all insurance remained public, was, in practice, $\mathrm{Ch} \$ 28,650$ for Isapre subscribers and just $\mathrm{Ch} \$ 11,770$ for those in FONASA. The Isapres have been able to engage in heavy indirect risk selection by oversupplying health plans, which discriminate by risk and income, in addition to inequity in access to benefits.

\section{The options in the case of Chile}

The existing health system has both public and private financing. Both public and private providers produce health services and, depending on whether subscribers are in the private Isapre system or in the public system (FONASA), they are free to choose between public or private suppliers, or both. However, individuals enrolled in the FONASA institutional care modality (MAI) may receive treatment only in State establishments. In addition, benefits included in the Regime of Explicit Health Guarantees (RGES) are financed in the public system with State contributions in the health-care network established for the purpose, and in the private system, through higher contributions from affiliates treated in the establishments determined by each Isapre.

\section{Data and evidence ${ }^{17}$}

With the inclusion of insurance markets as a financing mechanism, despite the obligatory contribution of

\footnotetext{
16 Data from the Central Bank of Chile, the Superintendence of Health and FONASA.

17 Data for the preparation of this paper were taken from the National Socioeconomic Survey (CASEN) of 2009. CASEN is run by the Ministry of Social Development (formerly the Ministry of Planning) and was conducted by the Social Observatory of Alberto Hurtado University. The survey was taken between November and December 2009 and included interviews of 71,460 households, corresponding to an expanded sample of $16,977,395$ inhabitants.
}

$7 \%$ of income, insurers have been able to charge high enough premiums to finance expected costs (claims plus administrative expenses). This has been achieved by offering a range of plans differentiated by premium, a price policy which has resulted in many high-risk, low-income individuals being unable to get insurance and migrating to the public system, FONASA.

There are five considerations that cast doubt on the use of private insurance as a mechanism of universal access to health care and protection. Two of these have to do with processes of exclusion, because of the way the system is designed: one between the insurance regimes (Isapres versus FONASA), and the other within each regime. The third is the loss of income compensation capacity (loss of solidarity) by treating social security contributions as voluntary private contributions. The fourth has to do with the difficulty in finding mechanisms to recover solidarity. The fifth is the heavy demand on public resources.

\section{(a) Exclusion by income (distribution) and risk (selection) in the Isapre system}

Exclusion from the private system and migration to the public system occur because the Isapres' risk selection mechanism pushes most of the lower-income and higher-risk population groups into the public system.

In table 3, Isapre affiliation rises with income level (by quintile). Affiliates' real possibility of choosing between the public and private systems is dictated by their ability to pay, not by their preferences. This runs counter to the original spirit of the reform and shows that only those in the fifth quintile can really choose between the systems according to their own preferences.

(b) Selection by income and risk within each modality The public health system covers $78.8 \%$ of Chile's population and assumes the care of the poorest segments (93.2\% of the first quintile). Those paying into the public system come under the responsibility of the Ministry of Health, with FONASA responsible for collecting and administering resources. FONASA operates as a social insurance, with a health plan executed by the agencies of the National System of Health Services and primary health-care establishments administered by municipal governments. The beneficiaries have access to this plan and are classified into different health groups by taxable income and number of dependants, from A for those who are indigent or without resources, to D for those with highest income. Thus there is one plan which works as 
Enrolment in health systems by quintile of independent income (*), 2009

(Percentages)

\begin{tabular}{|c|c|c|c|c|c|c|}
\hline \multirow{2}{*}{ Health system } & \multicolumn{6}{|c|}{ Income quintile } \\
\hline & I & II & III & IV & V & Total \\
\hline Public system & 93.2 & 90.3 & 85.1 & 72.3 & 44.6 & 78.8 \\
\hline Forces of law and order & 0.7 & 1.4 & 2.6 & 4.1 & 3.8 & 2.4 \\
\hline Isapre & 1.5 & 3.5 & 6.7 & 16.6 & 44.3 & 13.1 \\
\hline None (private) & 2.8 & 2.8 & 3.1 & 4.1 & 5.2 & 3.5 \\
\hline Other system & 0.5 & 0.3 & 0.5 & 0.5 & 0.4 & 0.4 \\
\hline Does not know & 1.4 & 1.7 & 2.0 & 2.4 & 1.6 & 1.8 \\
\hline Total & 100.0 & 100.0 & 100.0 & 100.0 & 100.0 & 100.0 \\
\hline
\end{tabular}

Source: Ministry of Social Development, Social Division, National Socioeconomic Survey (CASEN) of 2009 with expansion factors on the basis of the 2002 census.

(*) Does not include live-in domestic employees and their immediate family.

a solidarity system ${ }^{18}$ — with all benefits free for those with fewest resources and for the elderly — and another for people with more resources, whose characteristics are similar to a private insurance scheme with a copayment for care. 19

Certain institutional factors entrench the effects of risk selection in Chile and explain why over 12 million are enrolled in FONASA. In fact, the existence of the free choice modality (MLE) in FONASA encourages middle socioeconomic sectors into the public system, where they can combine the system's two access modalities.

The private health system (financed through the Isapres) represents $16.5 \%$ of the population, but $44.3 \%$ of the individuals with most resources. Its affiliates have access to a health system consisting of a series of providers among which they may chose freely. These institutions administer the contributions received and, sometimes, also deliver the health plan agreed upon. In this case, and in the absence of regulation, plans were created according to the characteristics of each beneficiary, on the basis that there are separation equilibria which identify individuals by risk and payment capacity. Today 51,171 different health plans ${ }^{20}$ exist with an average

\footnotetext{
18 Under the institutional care modality (MAI), beneficiaries may receive treatment in State establishments, where payment depends on their income group as defined in the Health Benefits Regime set forth in Law $\mathrm{N}^{\circ} 18.469$.

19 Under the free choice modality, beneficiaries may seek treatment from private health professionals or entities, or use State establishments and, in this case, in-patient stay-over facilities.

20 Of the 51,171 health plans, $12,727(24.9 \%)$ are being marketed (Superintendence of Health, 2011).
}

of 55 beneficiaries each, making it very difficult to compare plans as they have no common parameters. In terms of risk selection, it is estimated that more than 30 pathologies are considered "pre-existent", whereas FONASA does not apply this criterion.

\section{(c) Segmentation of the mandatory premium or loss of income compensation (solidarity) \\ Ultimately, the reform of 1981 divided access to the} health component of social protection between rich and poor, by means of various sorts of selection. Seventy-nine percent of the poorest part of the population remains in the public system, which lacks the contributions the higher-income sectors make to the health system; thus income solidarity within the system is lost.

The average level of premiums entering the Chilean health system from the collection of obligatory contributions, which could be gathered into a solidarity system, is quite considerable. Whereas with the average premium in the current public system, solidarity benefits up to the sixth decile, with the hypothetical average premium - with all affiliates contributing to a single system - solidarity would benefit up to the eighth decile, making for a clearly more egalitarian and equitable system $^{21}$ (see figure 1 ).

\footnotetext{
21 The results from the CASEN survey correspond to a sample and the information collected is, generally speaking, self-reported, so it includes certain biases with respect to administrative information. However, the conclusions are still valid insofar as the proportions are maintained with respect to census information.
} 
FIGURE 1

Average premium, per income decile and health system

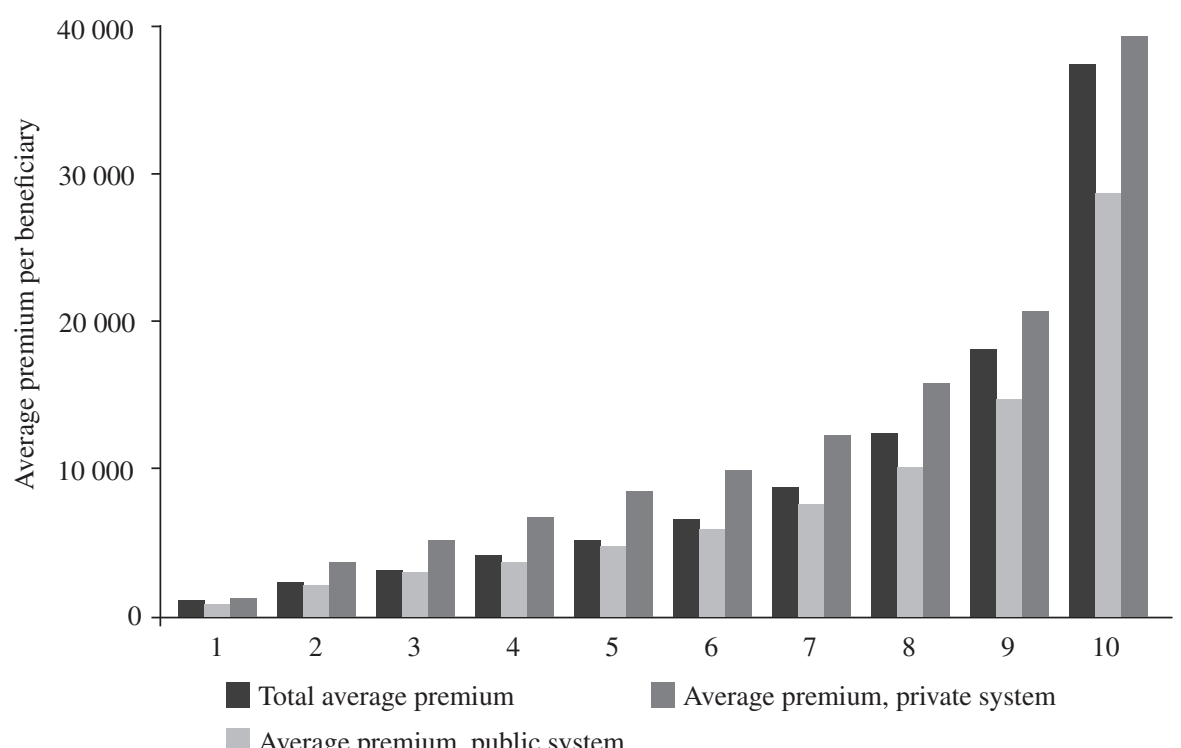

Source: prepared by the authors on the basis of National Socioeconomic Survey (CASEN) of 2009.

According to data from the Superintendence of Health, the Isapres collect $\mathrm{Ch} \$ 1.4$ billion per year, or $54 \%$ of the intake of the health system overall, to attend to only $16.5 \%$ of the population. This represents a large loss of resources which could help the public health system to meet the objective of being more equitable and solidary. ${ }^{22}$ Figure 2 shows that contributions to the public sector are made mainly by the lower deciles, contrary to the private system in which contributions rise in the higher income deciles.

A Lorenz curve ${ }^{23}$ for Chilean's independent income alongside the concentration curves for health premium collections clearly shows how the Chilean health system overall reflects income inequalities, since the concentration curve for the system's total intake is very similar to the Lorenz curve. Breaking down the total premium collection by health system shows that public system collection corresponds to income in a more egalitarian manner, whereas the private system collection is clearly concentrated in the higher-income sectors. This gives rise to a system in which the poorest (concentration curve for the public system)

\footnotetext{
22 For 2010, total collection by Isapres comprised: legal contributions, $7 \%$ (Ch\$ 976,406,000), voluntary contributions (Ch\$365,229,000), employers' contributions $(\mathrm{Ch} \$ 33,599,000)$ and income from the compensation fund ( $\mathrm{Ch} \$ 668$ million).

23 See Lorenz (1905).
}

contribute more to the solidarity system, while the richest contribute to the private system for buying individual, not social, insurance. ${ }^{24}$ So, in the public system -into which lower-income segments pay more- contributory solidarity applies, whereas in the private system - into which highest-income individuals pay - the principle of equivalence predominates to the detriment of solidarity.

(d) Difficulty of regaining balance between equivalence and solidarity (explicit health-care guarantees)

These outcomes have not gone unremarked in Chile. But, given the political framework inherited from the military regime and the vested interests in the health system, progress with reform has been limited. One such reform was the Regime of Explicit Health Guarantees (RGES), also known as the System of Universal Access with Explicit Guarantees (AUGE Plan). This aimed to establish a charter of health rights and duties and thus provide the population (regardless of socioeconomic status or enrolment in one health system or the other) with a list of health-care benefits for which the State would assume responsibility (see box 1). AUGE ensures solidary financing by eliminating the conflict with equivalence for at least one set of benefits for which the State will

24 In which the premium is determined by the risk of the individual, not of a larger group of individuals. 
FIGURE 2

Total contributions to the health system by income decile and health system

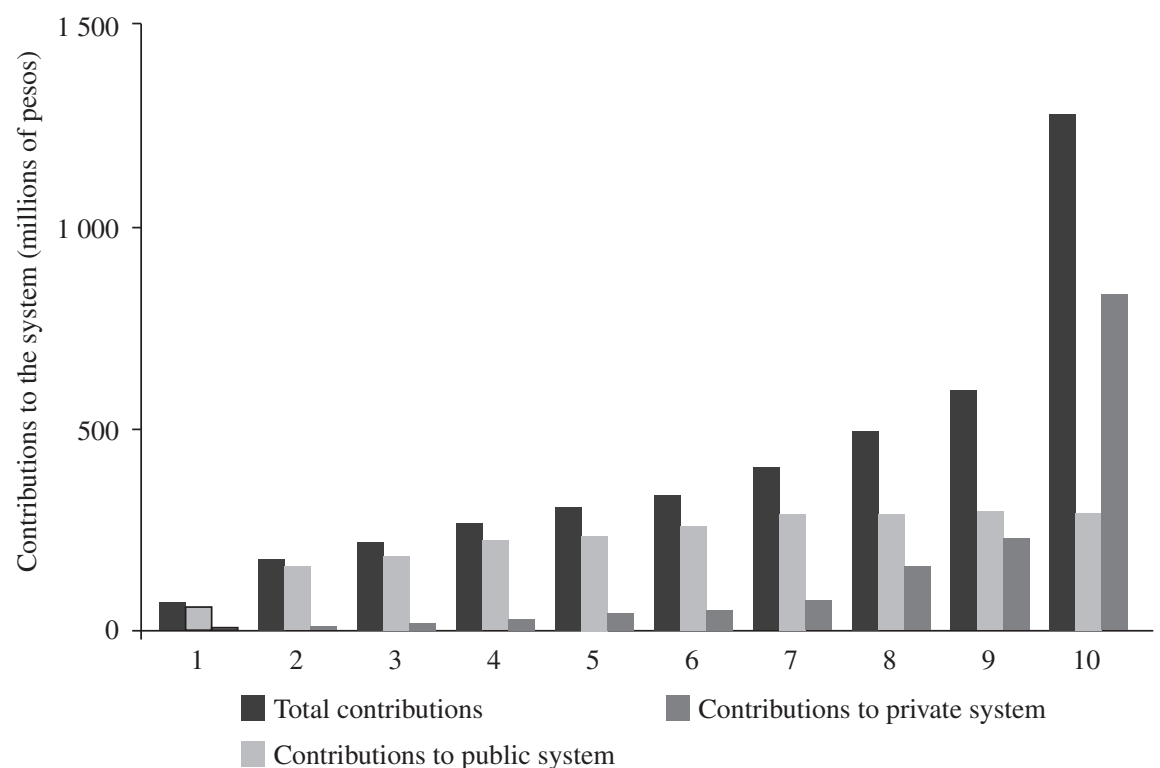

Source: prepared by the authors on the basis of National Socioeconomic Survey (CASEN) of 2009.

FIGURE 3

\section{Concentration and Lorenz curves}

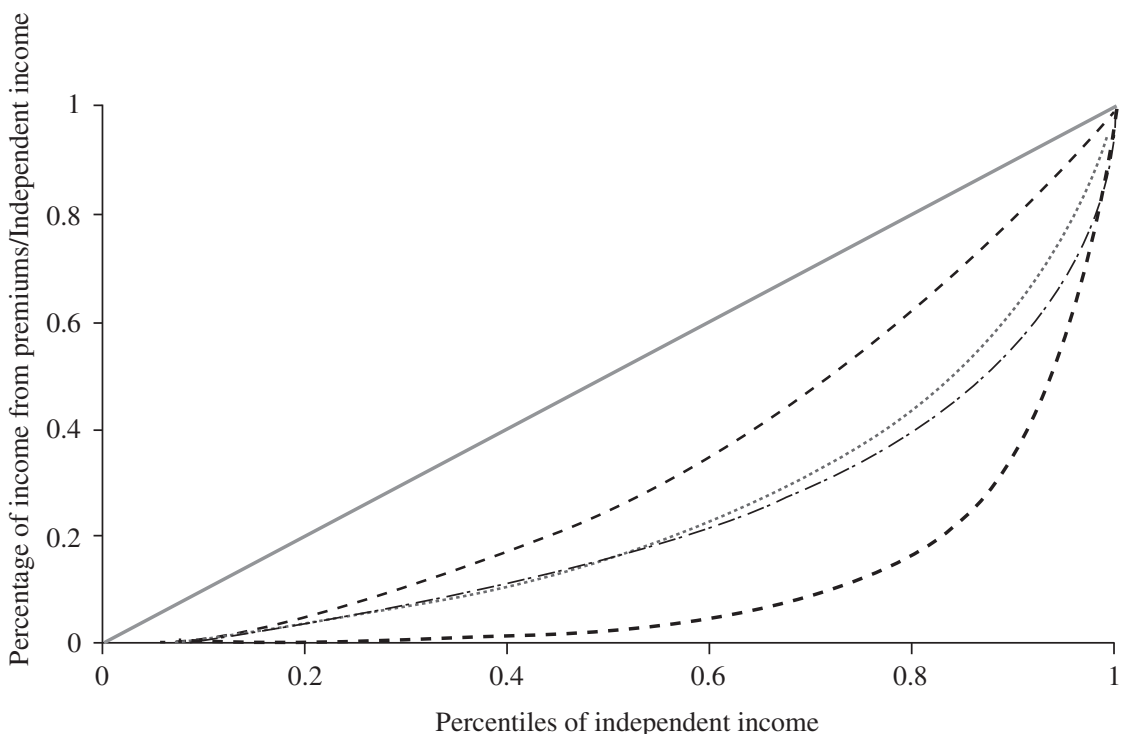

$45^{\circ}$ line

- - - - - . Lorenz curve

Concentration total premiums

Concentration private premiums

- - - - . Concentration public premiums

Source: prepared by the authors on the basis of National Socioeconomic Survey (CASEN) of 2009. 
pay, a set which will be extended as resources become available. However, when the AUGE legislation was passed, the creation of a solidary fund was not approved.

In order to reduce risk selection, the basic plan under RGES includes the highest-risk diseases, increasing coverage and access and including guarantees of quality and timeliness. Private insurers may set their own price to reflect differences in service, benefit quality and standard of accommodation; they also receive a fixed payment through a community rating 25 system for individuals availing themselves of AUGE benefits.

25 As practised by various countries, community rating is equivalent to a per capita payment set according to the population's average risk level. This makes it imperative to take steps to bring independent and informal workers into the system, in order to improve the distribution of average risk and thereby lower average spending by the State.
RGES is meant to establish a long-term health system. Regulation is supposed to: (i) establish a benchmark plan and largely eliminate the numerous existing plans; ${ }^{26}$ (ii) make public hospitals more efficient and autonomous, and make private providers more transparent, and make the two more complementary and aligned with the societal objectives of AUGE; (iii) establish rules on co-payments and obligations, including access (which FONASA was already obliged to provide and Isapres are now instructed to provide), quality (benefits can be provided only by a registered and accredited provider), financial protection (co-payments are regulated, and in some cases must be zero) and timeliness of access (waiting lists for treatment are regulated) (Sojo, 2006).

26 Cost containment and gradual reduction of administrative expenses.

BOX 1

Explicit health-care guarantees plan (GES) (formerly AUGE)

The explicit health-care guarantees plan (GES) — formerly AUGE - seeks to avoid exclusion by morbidity status or entry conditions, by guaranteeing coverage by FONASA and Isapres for a number of health problems. Today GES covers 69 pathologies, and this range will increase over time. GEs benefits apply to all these pathologies, regardless of whether they were diagnosed before or after the plan was set up. GES includes the right to a free preventive care check-up once a year for timely detection of certain diseases. The beneficiary may also have the right to free medication, depending on the particular health problem.

Diseases not included in the GES plan have the normal coverage set forth in the individual's health plan. For certain lifethreatening, high-cost conditions, GES provides additional coverage for catastrophic illnesses (CAEC). In the case of FONASA the catastrophic conditions insurance covers $100 \%$, i.e. there is no additional cost of the beneficiary, providing treatment is delivered in the institutional modality (MAI). In the Isapre system, additional coverage for catastrophic illness gives affiliates $100 \%$ coverage within the closed network of providers.

The purpose of additional coverage for catastrophic illness is to explicitly ensure: (i) access: obliging FONASA and the Isapres to assure health care; (ii) quality: demanding the delivery of guaranteed health care by a registered or accredited provider; (iii) timeliness: setting a deadline for the provision of the guaranteed care, at the stages of diagnosis, treatment and follow-up, and (iv) financial protection: capping the contribution, payment or co-payment the affiliate may be charged for a treatment or set of treatments, taking income into account.

In the event of a GES-covered illness, the plan is triggered in either FONASA or an Isapre, with a doctor's certificate showing the diagnosis and a special form, which refers the patient to a provider for confirmation of the diagnosis. If this is confirmed, the patient is referred to an establishment in the network of providers.

Here the Isapres and FONASA operate as preferred provider organizations (PPOs), with closed networks of providers for GES conditions. Patients may also opt to seek treatment with extra coverage from top-up plans.

In the case of FONASA, payments vary by vulnerability level and are subject to caps. Isapre affiliates pay $20 \%$ of the treatment - according to the reference rate available in each Isapre - with a cap on contributions by number of illnesses. The health plan itself also carries an additional charge for access to GES. The price varies by Isapre, but averages $\mathrm{Ch} \$ 5,500$ per affiliate.

When timeliness and access guarantees are not fulfilled, FONASA or the Isapre in question must provide treatment through the network of providers.

In the event that the financial protection guarantee is not met, beneficiaries may appeal to the Superintendence of Health, which resolves certain disputes relating to this problem and rules on the qualification or not of a disease for GES coverage.

Source: National Health Fund (FONASA) and Ministry of Health of Chile. 
In 2010, with a view to endowing the system with the necessary solidarity, the State transferred to FONASA $\mathrm{Ch} \$ 2.3$ billion pesos to subsidize care for the poorest sectors of the population (see tables 4 and 5). This is equivalent to an additional per capita premium of $\mathrm{Ch} \$ 191,537$ per year (Ch\$15,961 per month) and represents almost double the premium paid by group $\mathrm{B}, 133 \%$ of the group $\mathrm{C}$ premium and $86 \%$ of the group D premium. Of this amount, $39 \%$ is allocated to coverage for the poorest. Among those who pay into the system and are enrolled with FONASA, the most generous contribution goes to groups B (37.1\%) and D (16.7\%). Group C benefits least, with $7.6 \%$.

\section{(e) Implications for public finances in the future}

As Panel A of figure 4 shows, age is a key factor in risk selection. Isapres show a clear tendency to select by age, as is evident in Panel B.

Chile is going through the final stages of the fertility translation. It will be another decade before the demographic dependency ratio begins to rise, but the proportion of older adults has already risen (Uthoff, 2010). If the current trends as regards risk selection and solidarity financing continue, it is likely that:

- $\quad$ Age groups with greater health-risk factors will increase vis-à-vis the rest of the population. The composition of the growing age groups in relation to the working-age population will change, as well, with fewer children and more older persons (see figure 5). This will significantly increase spending on health and pensions.

- The State will have to increase financing for the system owing to the coming demographic shift.

- Public health spending needs will rise significantly (see figure 6).

Affiliations will tend increasingly to migrate to public health insurance, owing to the effects of risk section by sex and age by the Isapres.

\section{Breakdown of public health sector spending and financing, 2010} (Millions of pesos)

\begin{tabular}{|c|c|c|c|c|c|c|c|c|c|}
\hline \multirow[b]{2}{*}{ Health group } & \multicolumn{4}{|c|}{ Expenditures } & \multicolumn{5}{|c|}{ Financing } \\
\hline & $\begin{array}{c}\text { Incidences } \\
\text { of medical } \\
\text { treatment }\end{array}$ & $\begin{array}{c}\text { Work } \\
\text { incapacity } \\
\text { allowance }\end{array}$ & $\begin{array}{l}\text { Administrative } \\
\text { costs }\end{array}$ & Total & Contributions & Co-payments & $\begin{array}{l}\text { Group } \\
\text { subsidies }\end{array}$ & $\begin{array}{c}\text { State } \\
\text { contribution }\end{array}$ & Total \\
\hline A & 903905 & 0 & 0 & 903905 & 0 & 0 & & 903905 & 903905 \\
\hline B & 1202725 & 121444 & 12694 & 1336863 & 406022 & 60554 & & 870287 & 1336863 \\
\hline $\mathrm{C}$ & 441918 & 66116 & 6911 & 514945 & 314117 & 21662 & & 179166 & 514945 \\
\hline $\mathrm{D}$ & 736937 & 160418 & 16768 & 914123 & 464448 & 57034 & & 392641 & 914123 \\
\hline Total & 3285485 & 347978 & 36373 & 3669836 & 1184587 & 139251 & 0 & 2345998 & 3669836 \\
\hline
\end{tabular}

Source: prepared by the authors on the basis of:

- Statistics and budget statements of the National Health Fund (FONASA) and the National System of Health Services (SNSS).

- National Socioeconomic Survey (CASEN) of 2006, Ministry of Social Development.

Notes:

(1) Does not include spending on public health goods and investments.

(2) Incidences of medical treatment: corresponds to spending on both institutional care and free choice modalities (MAI and MLE). Does not include municipal contributions for primary care.

(3) Work incapacity allowance (SIL): includes SIL expenditures by Regional Ministerial Offices (SEREMI) and Family Allowance Funds (CCAF).

(3) Administrative costs: corresponds to internal operating expenditures by FONASA.

(4) Since main FONASA spending efforts are concentrated in the free choice modality (MLE) and SIL, and the distribution of administrative costs goes mainly to these items, the allocation of these expenditures to group A affiliates receiving these benefits is very marginal and is assumed to be nil for the purposes of this study.

(5) Contributions: affiliates' contribution of $7 \%$ of income. Includes $0.6 \%$ which goes directly to CCAF.

(6) Co-payments: corresponds to co-payments for MLE and for the explicit guarantees (GES) plan, assuming 10\% SNSS income as co-payment for the institutional care system (MAI).

(7) Group subsidies: since the expenditures of each health group are far higher than the affiliate contributions and co-payments, subsidies are non-existent.

(8) State contribution: contributions to FONASA from taxes and from the Chile crece contigo programme, and municipal contribution to primary health care. 
TABLE 5

Breakdown of expenditures and financing per capita in the public health sector, 2010 (Pesos)

\begin{tabular}{|c|c|c|c|c|c|c|c|c|c|}
\hline \multirow[b]{2}{*}{ Health group } & \multicolumn{4}{|c|}{ Expenditures } & \multicolumn{5}{|c|}{ Financing } \\
\hline & $\begin{array}{c}\text { Incidences } \\
\text { of medical } \\
\text { treatment }\end{array}$ & $\begin{array}{c}\text { Work } \\
\text { incapacity } \\
\text { allowance }\end{array}$ & $\begin{array}{c}\text { Incidences } \\
\text { of medical } \\
\text { treatment }\end{array}$ & $\begin{array}{c}\text { Work } \\
\text { incapacity } \\
\text { allowance }\end{array}$ & $\begin{array}{c}\text { Incidences } \\
\text { of medical } \\
\text { treatment }\end{array}$ & $\begin{array}{c}\text { Work } \\
\text { incapacity } \\
\text { allowance }\end{array}$ & $\begin{array}{c}\text { Incidences } \\
\text { of medical } \\
\text { treatment }\end{array}$ & $\begin{array}{c}\text { Work } \\
\text { incapacity } \\
\text { allowance }\end{array}$ & Total \\
\hline A & 234114 & 0 & 0 & 234114 & 0 & 0 & & 234114 & 234114 \\
\hline B & 292049 & 29489 & 3082 & 324620 & 98591 & 14704 & & 211325 & 324620 \\
\hline $\mathrm{C}$ & 202148 & 30244 & 3161 & 235553 & 143687 & 9909 & & 81956 & 235552 \\
\hline Total & 1082107 & 136748 & 14293 & 1233148 & 465255 & 51994 & 0 & 715898 & 1233147 \\
\hline
\end{tabular}

Source: prepared by the authors on the basis of:

- Statistics and budget statements of the National Health Fund (FONASA) and the National System of Health Services (SNSS).

- National Socioeconomic Survey (CASEN) of 2006, Ministry of Social Development.

Notes:

(1) Does not include spending on public health goods and investments.

(2) Incidences of medical treatment: corresponds to spending on both institutional care and free choice modalities. Does not include municipal contributions for primary care.

(3) Work incapacity allowance (SIL): includes SIL expenditures by Regional Ministerial Offices (SEREMI) and Family Allowance Funds (CCAF).

(3) Administrative costs: corresponds to internal operating expenditures by FONASA.

(4) Since main FONASA spending efforts are concentrated in the free choice modality (MLE) and SIL, and the distribution of administrative costs goes mainly to these items, the allocation of these expenditures to group A affiliates receiving these benefits is very marginal and is assumed to be nil for the purposes of this study.

(5) Contributions: affiliates' contribution of $7 \%$ of income. Includes $0.6 \%$ which goes directly to CCAF.

(6) Co-payments: corresponds to co-payments for MLE and for the explicit guarantees (GES) plan, assuming 10\% SNSS income as co-payment for the institutional care system (MAI).

(7) Group subsidies: since the expenditures of each health group are far higher than the affiliate contributions and co-payments, subsidies are non-existent.

(8) State contribution: contributions to FONASA from taxes and from the Chile crece contigo programme, and municipal contribution to primary health care.

FIGURE 4

A. Age and sex as risk selection factors in Chile

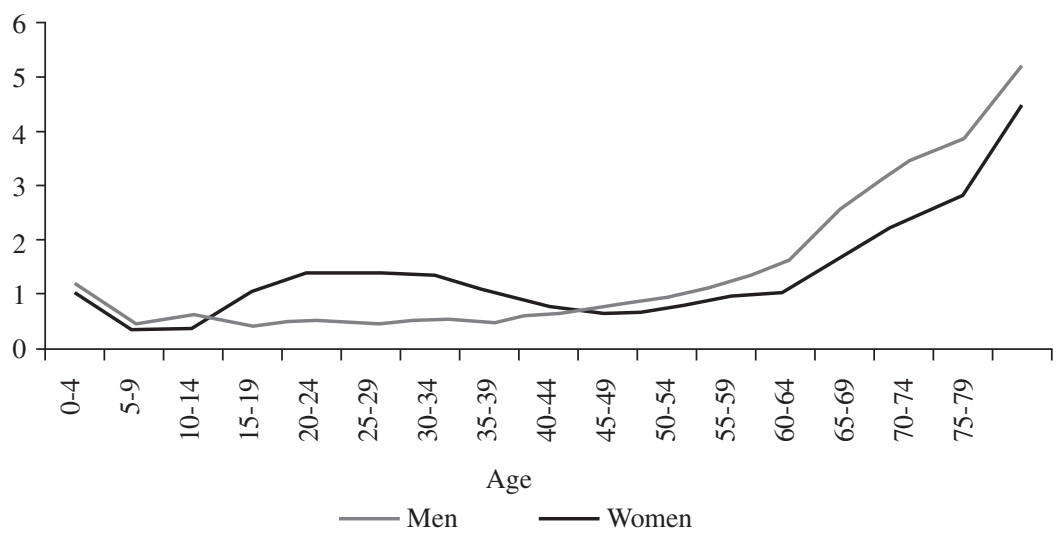


Figure 4 (concluded)

\section{B. Public and private insurance by age} (Percentages)

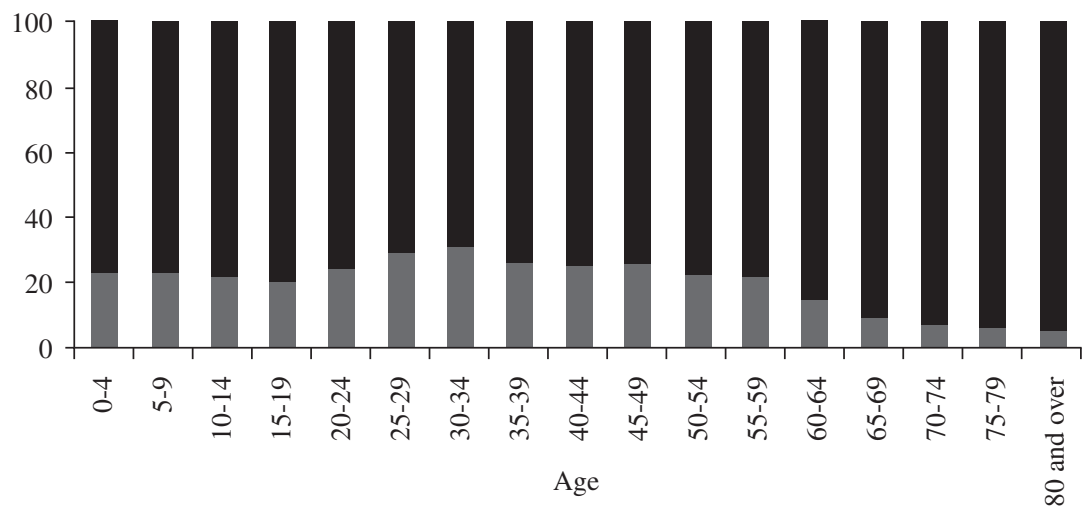

Isapres FONASA

Source: prepared by the authors on the basis of data from the Ministry of Health of Chile on affiliation, risk factors by sex and age and five-year age groups in relation to per capita cost.

FIGURE 5

Population by age group relative to the population aged 20-65

(Number of persons in each age group per working-age person (aged 20 - 65)

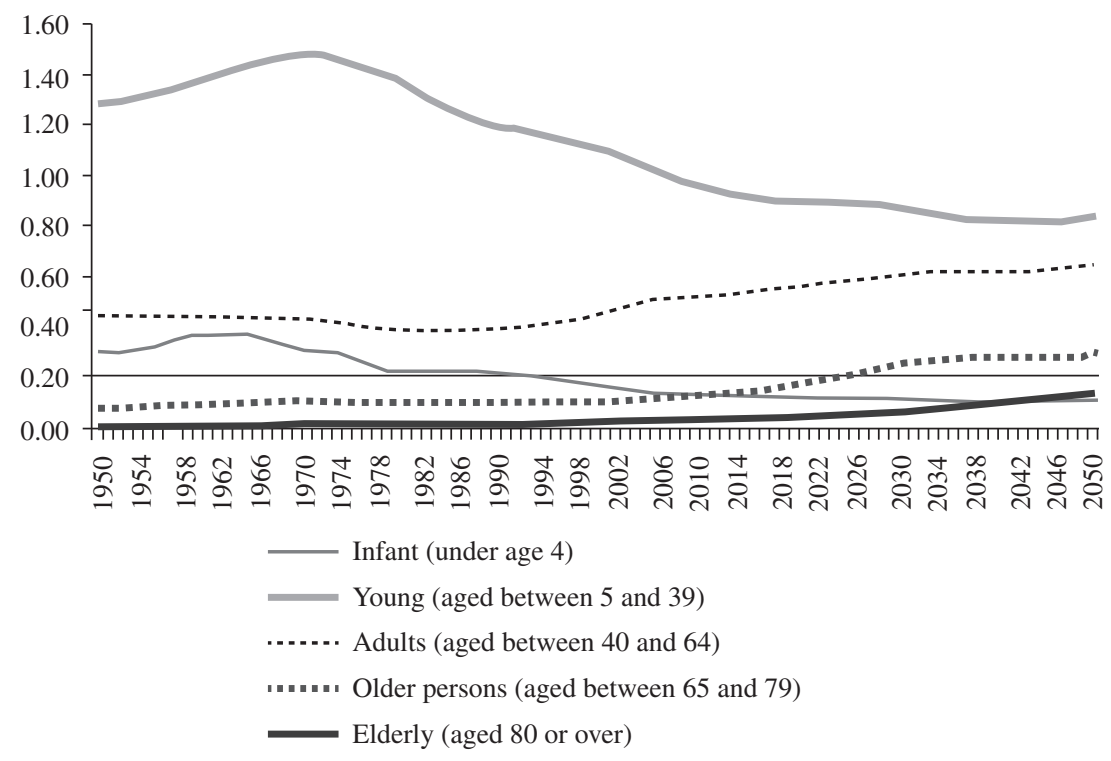

Source: prepared by the authors on the basis of population estimates and projections by age from the Latin American and Caribbean Demographic Centre (CELADE)-Population Division of ECLAC. 
FIGURE 6

Effect of demographic trends on public health spending and affiliation Projected total health spending as a percentage of GDP

(Scenario adjusted by per capita GDP)

Projected health spending

(Billions of pesos)

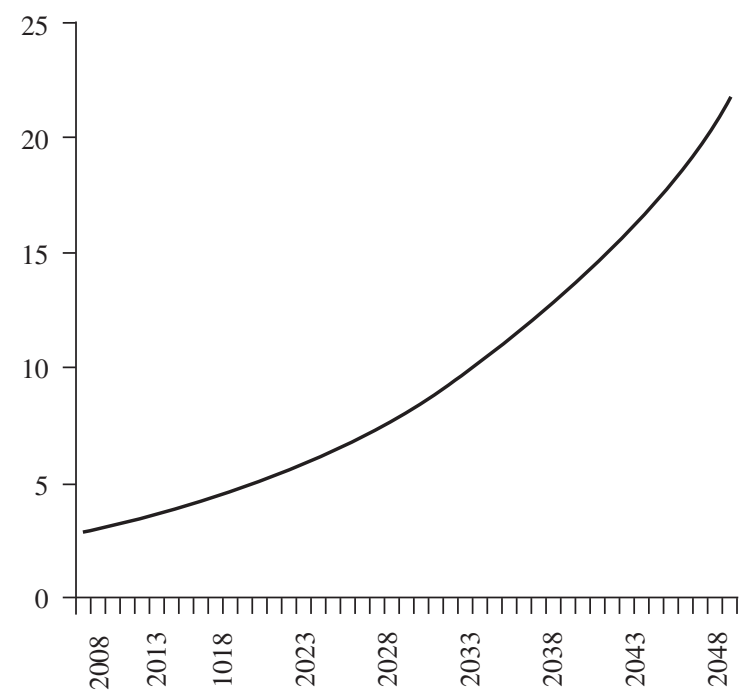

Projected health spending (Percentages of GDP)

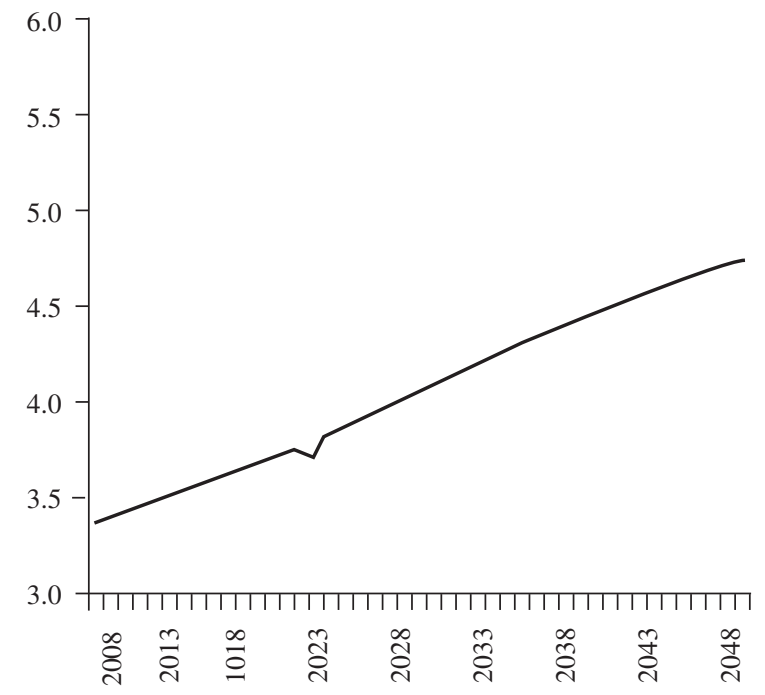

Projected market share

(Billions of pesos)

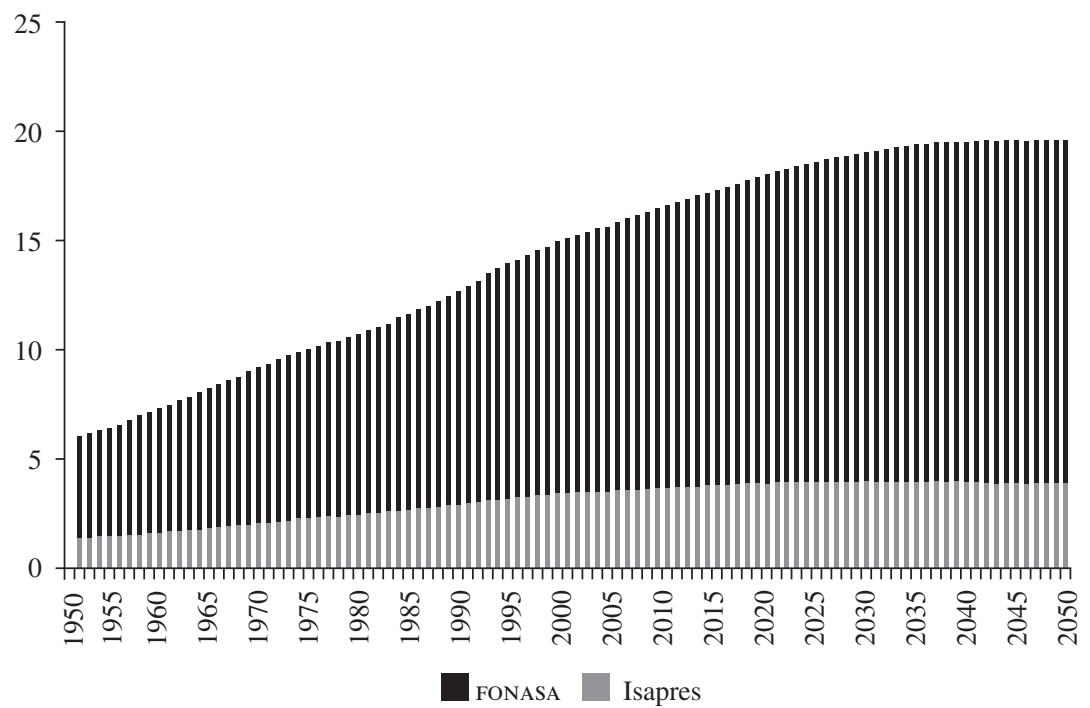

Source: prepared by the authors on the basis of data from the Ministry of Health (MINSAL), the Latin American and Caribbean Demographic Centre (CELADE)-Population Division of ECLAC and the Central Bank of Chile.

GDP: gross domestic product. 


\section{V}

\section{Conclusions and final remarks}

As public health schemes, competitive markets for individual health insurance are running into difficulties the world over, as a result of pricing policy that tends to set premiums on the basis of foreseeable individual losses (i.e. according to the principle of equivalence). In the absence of proper regulation, this policy forces insurers to select risk and therefore to exclude the poor or those with high risk. This runs counter to the universal coverage required of a public system (i.e. the principle of solidarity).

The experience in countries which apply this sort of policy (Belgium, Germany, Israel, the Netherlands and Switzerland, among others) is that risk and income solidarity have to be factored into the insurance market in order to achieve universal coverage. To this end, all these countries have implemented some sort of riskadjusted premium subsidy (or risk equalization among risk groups), together with strict regulation of the direct premiums paid to insurers by affiliates. In all cases, these risk-adjustment mechanisms are imperfect and, according to expert opinion, they must be improved if insurance markets are to remain operational.

In Chile, as part of public health funding, a public insurance with income-based contributions was launched and private administration of health insurance was allowed through individual contracts. The idea was to reduce State involvement in health care and move towards a system of individual insurance. An obligatory premium was set (to avoid adverse selection) at $7 \%$ of independent income and the health system was opened to private operators.

In principle, with strictly regulated risk adjustment, contributions by income level could produce vertical and horizontal equity by inducing redistribution from healthy to sick, and from rich to poor. Without appropriate regulation, however, this new health insurance market encouraged insurers to give priority to the principle of equivalence, adapting premiums to expected costs and thereby generating heavy direct and indirect risk selection and contravening the principle of solidarity (of crosssubsidies from rich to poor and from healthy to sick).
Today there are over 50,000 private health plans in the market, differentiated by individual risk. This has led to market-skimming and allowed the development of a dual model, with a private insurance market for the rich and public insurance for everyone else. The private market offers plans that are excessive in relation to real needs, with clear surpluses, while the public insurance covers $78 \%$ of the population, including those with lowest incomes and highest risk (including women of childbearing age, the chronically ill, the elderly and the poor). In the public system, indigents have no option other than public health provision, while non-indigent can opt for free choice modalities with co-payment. The private system has no risk equalization mechanism and displays serious problems of risk selection, with plans varying by mandatory premium and the affiliate's voluntary top-up.

The AUGE-GES system provides explicit guarantees by substantially reducing out-of-pocket expenditure. But problems remain with private insurers skimming risk from the public sector. Between 2005 when the GES system was set up and mid-2010, 12 times more guarantees were processed in the public system than in the private system, while the public system population numbered only five times the population in the private system. This bears out the hypothesis of skimming and shows that the public system comprises not only the poorest and most vulnerable, but also those with highest risk, including the chronically ill and the elderly (of whom 90\% are in the public sector (Erazo, 2011)).

The financing of the Chilean system needs to be rethought in order to even out these inequalities. The current situation, far from reducing State involvement, engages the State even more heavily and, what is more, does so in a way that does not fully balance equivalence with solidarity. The solution necessarily lies in either consolidating the contributions from all affiliates (Isapres and FONASA) under a social security rationale or considering a tax reform. In either case, better regulation of the system is needed to delineate risk-adjustment schemes and guarantee basic packages of benefits. 


\section{Bibliography}

Barr, N. (2003), "Economic theory: state intervention", The Economics of the Welfare State, Oxford, Oxford University Press.

Castro, R. and F. Bahamondes (2008), "Fallo Isapres: ¿Es posible en Chile descorrer el velo a la colusión?", Anuario de derecho constitucional latinoamericano, Buenos Aires, Konrad-Adenauer Stiftung Foundation.

Cid, C. and L. Prieto (2011), "Inequidad en el financiamiento de la salud y su impacto en la distribución del ingreso en Chile", presentation at the XXXI Jornadas de Economía de la Salud, Palmas de Mallorca, España.

ECLAC (Economic Commission for Latin America and the Caribbean) (2006), Shaping the Future of Social Protection: Access, Financing and Solidarity (LC/G.2294(SES.31/3)), Santiago, Chile.

Enthoven, A.C. and W.P.M.M. Van de Ven (2007), "Going Dutch managed-competition health insurance in the Netherlands", The New England Journal of Medicine, vol. 357, No. 4, December.

Erazo, A. (2011), "La protección social en Chile. El Plan AUGE: Avances y desafíos", Financiamiento del desarrollo series, No. 208 (LC/L.3348), Santiago, Chile, Economic Commission for Latin America and the Caribbean (ECLAC).

Larrañaga, O. (1997) "Eficiencia y equidad en el sistema de salud chileno", Financiamiento del desarrollo series, No. 49 (LC/L.1030), Santiago, Chile, Economic Commission for Latin America and the Caribbean (ECLAC).

Lorenz, M. (1905), "Methods of measuring the concentration of wealth", Publications of the American Statistical Association, vol. 9, No. 70, American Statistical Association.

Maarse, H. and Aggie Paulus (2011), "The politics of health-care reform in the Netherlands since 2006", Health Economics, Policy and Law, vol. 6, No. 1, Cambridge, Cambridge University Press.

Martínez, A. and E. León (2011), "Estructura y comportamiento del sistema de salud en Chile" [online] http://www.cybertesis. uchile.cl/tesis/uchile/2011/ec-leon_v/pdfAmont/ec-leon_v.pdf.

Schut, F. and W.P.M.M. Van de Ven (2011a), "Effects of purchaser competition in the Dutch health system: is the glass half full or half empty?", Health Economics, Policy and Law, vol. 6, No. 1, Cambridge, Cambridge University Press.

(2011b), "Managed competition in the Dutch Health system: is there a realistic alternative?", Health Economics, Policy and Law, vol. 6, No. 1, Cambridge, Cambridge University Press.

Sojo, A. (2006), "La garantía de prestaciones en salud en América Latina. Equidad y reorganización de los cuasimercados a inicios del milenio", Estudios y perspectivas series, No. 44 (LC/MEX/L.708), Mexico City, ECLAC subregional headquarters in Mexico.
Superintendencia de Salud (2011), Análisis de los planes de salud del sistema ISAPRE. Enero de 2011, Santiago, Chile, Departamento de Estudios y Desarrollo.

Titelman, D. (2000), "Reformas al sistema de salud en Chile: Desafíos pendientes", - Financiamiento del desarrollo series, No. 104 (LC/L.1425-P), Santiago, Chile, Economic Commission for Latin America and the Caribbean (ECLAC). United Nations publication, Sales No. S.00.II.G.99.

(1999), "Reform to health system financing in Chile", CEPAL Review, No. 69 (LC/G.2067-P), Santiago, Chile.

Titelman, D. and A. Uthoff (2000), Ensayos sobre el financiamiento de la seguridad social en salud: los casos de Estados Unidos, Canadá, Argentina, Chile, Colombia, Santiago, Chile, Economic Commission for Latin America and the Caribbean (ECLAC)/ Fondo de Cultura Económica.

Tokman, M., C. Marshall and C. Espinoza (2007), "Un matrimonio difícil: La convivencia entre un seguro público solidario y seguros de salud competitivos", Financiamiento del desarrollo series, No. 199 (LC/L.2851-P), Santiago, Chile, Economic Commission for Latin America and the Caribbean (ECLAC). United Nations publication, Sales No. S.07.II.G.175.

Uthoff, A. (2010), "Transferencias intergeneracionales en América Latina: Su importancia en el diseño de los sistemas de protección social" (LC/W.336), Santiago, Chile.

Van de Ven, W.P.M.M. and F. Schut (2011), "Guaranteed access to affordable coverage in individual health insurance markets", The Oxford Handbook of Health Economics, Oxford University Press. (2009), "Managed competition in the Netherlands: still work in progress", Health Economics, vol. 18, No. 3, John Wiley \& Sons. (2008), "Universal mandatory health insurance in the Netherlands: a model for the United states?", Health Affairs, vol. 27, No. 3

Van de Ven, W.P.M.M. and others (2007), "Risk adjustment and risk selection in Europe: 6 years later", Health Policy, vol. 83, No. 2-3, Amsterdam, Elsevier. (2003), "Risk adjustment and risk selection on the sickness fund insurance market in five European countries", Health Policy, vol. 65, No. 1, Amsterdam, Elsevier.

Wilkinson, W. (2006), "Health Care Fantasia", 19 March [online] http:// willwilkinson.net/flybottle/2006/03/19/health-care-fantasia/. 